\title{
Reduction of Odors from Composting Processes Using an Ecological Method
}

\author{
Monika Iwona Gałwa-Widera' \\ 1 Czestochowa University of Technology, ul. Dąbrowskiego 69, 42-200 Częstochowa, Poland \\ E-mail: mwidera@is.pcz.czest.pl
}

\begin{abstract}
The complete elimination of odorants from the gases released into the atmosphere is a practically impossible task. This is mainly due to the fact that they are released not only during the technological process itself, but also during unloading, reloading, and transport, which are components of the technological line and also sources of emissions. It is not always possible to encapsulate these stages. Many gases belonging to the group of odorous compounds, characterized by unpleasant odors, have a very low detection threshold. Thus, for the odor to be imperceptible, the compound must be completely removed from the exhaust gas. This task would involve the necessity to take into account the complete air-tight sealing already at the stage of design and construction of the installation. This article concerns the tests carried out in the composting plant in the field of protection against odors. In the experiment, a biofilter with a permanent filling with full process monitoring was used. The research was carried out to determine the process parameters for the real object.
\end{abstract}

Keywords: biofiltration, odory, kompostowanie, przemysł

\section{INTRODUCTION}

The complete elimination of odorants from the gases released into the atmosphere is a practically impossible task. This is mainly due to the fact that they are released not only during the technological process itself, but also during unloading, reloading, and transport, which are components of the technological line and also sources of emissions. It is not always possible to encapsulate these stages.

Many gases belonging to the group of odorous compounds, characterized by unpleasant odors, have a very low detection threshold. Thus, for the odor to be imperceptible, the compound must be completely removed from the exhaust gas. This task would involve the necessity to take into account the complete air-tight sealing already at the stage of design and construction of the installation [Twardowski and Michalska, 2000; Warych, 1998].

This scientific article concerns the tests carried out in the composting plant in the field of protection against odors. In the experiment, a biofilter with a permanent filling with full process monitoring was used.

The research was carried out to determine the process parameters for the real object. They consist of:

- introduction of a volatile deodorant,

- oxidation of odorous compounds,

- chlorination

- thermal or catalytic disposal.

This group also includes the methods that use sorption processes. The second group of methods, belonging to the group of ecological processes, includes biological methods:

- the use of biological scrubbers,

- the use of biofilters based on natural materials and microorganisms.

In biological washers, activated sludge is used as the filter layer. It is a suspension of microorganisms in water. Filtration uses the activity of heterotrophic aerobic bacteria to which contaminated gas is supplied in counter-current. 
Microorganisms can self-clean the sorbent in the aerated chamber. After such self-regeneration, the stream is returned to the scrubber. A similar principle, despite a slightly different structure, is used in the filters with permanent filling.

Here, the main element is a layer of highly porous filter material. Such a bed is inhabited by microorganisms capable of the biological decomposition of air pollutants. The contaminated gases are passed through the bed. There is a chemical process such as sorption on the filter material and a biological process involving the decomposition of pollutants by active microorganisms. As in the case of bio-scrubbers, susceptibility to self-regeneration is observed here.

The research conducted in recent years shows that the biological methods are as effective as the chemical or physical methods (Ilski K 2008). They are perfect for neutralizing volatile pollutants, both those associated with the formation of odors and volatile organic compounds. The process of decomposition of pollutants taking place in the biofilter is carried out owing to the activity of bacteria, fungi, and actinomycetes forming an active biofilm on the sorbent surface.

During the flow of polluted gas through the layer of filter material, the diffusion of pollutants from the gas phase into the biologically active layer surrounding the particles of the filter material (Schiffman, 2005) - the biofilm. The microorganisms that can break down more pollutants develop owing to biomass.

Biofilters can be of various shapes and sizes. It depends on the type and size of the process in which odor compounds are produced. There are also different methods of supplying air. Most often, large-size containers with heights of up to several meters are used. In case of high pollution load, a system of combined biofilters can be used. The biofiltration gases should be humidified to $95-100 \%$ relative humidity. In this situation, humidifying the supplied gases, consisting in supplying the gas stream with water vapor through the steam humidifier, is a perfect solution.

Condensation occurs in the biofilter during the process. The condensate can be used to resprinkle the filter bed or be discharged for treatment. This applies to encapsulated biofilters. In the case of open biofilters, the leachate from rainwater is drained. Biofiltration is not a homogeneous process. It runs in the liquid and gas phase, and its result involves biodegradation products:
$\mathrm{CO}_{2}, \mathrm{H}_{2} \mathrm{O}$, and other inorganic compounds. The odor pollutants contained in the flowing air are adsorbed on the liquid surface of the biofilm covering the particles of the filter material. The molecules of odor compounds adsorbed on the surface of the biolayer pass into the liquid phase and diffuse towards the microorganisms inhabiting the biofilm.

The process on the surface of the biofilter particles is the decomposition of pollutants and is called biodegradation. The second stage of biodegradation is mineralization. It is based on the enzymatic decomposition of organic compounds by microorganisms using energy and biogenic elements. After that, simple mineral products are expelled. The decomposition of organic molecules takes place inside the cell.

Macromolecular compounds, such as proteins, cellulose, or other natural and synthetic polymers, are hydrolyzed outside the cell. The products of this decay enter the body and are oxidized there. These transformations take place under aerobic conditions (Cain 1978, Philpott and Bennett 2008). The result of the biological decomposition of the pollutants absorbed in the biolayer is the self-regeneration of the filter material on the surface of which there is a biofilm.

The porosity of the bed, i.e. the size and distribution of grains and the pore structure, must

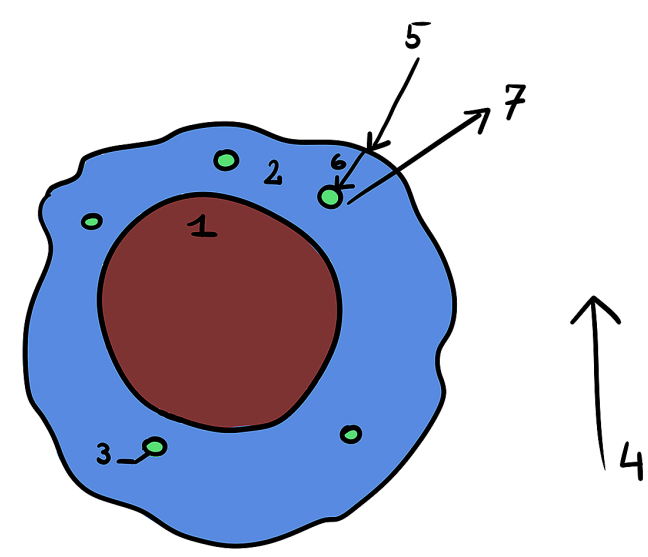

Fig. 1. Scheme of the pollutant decomposition process by microorganisms.

1. Particle of filling

2. The water phase, the environment of microorganisms

3. Microorganisms

4. Direction of the polluted airflow

5. Adsorption of pollutants

6. Diffusion of pollutants and oxygen

7. Biomass growth and removal of decomposition products 


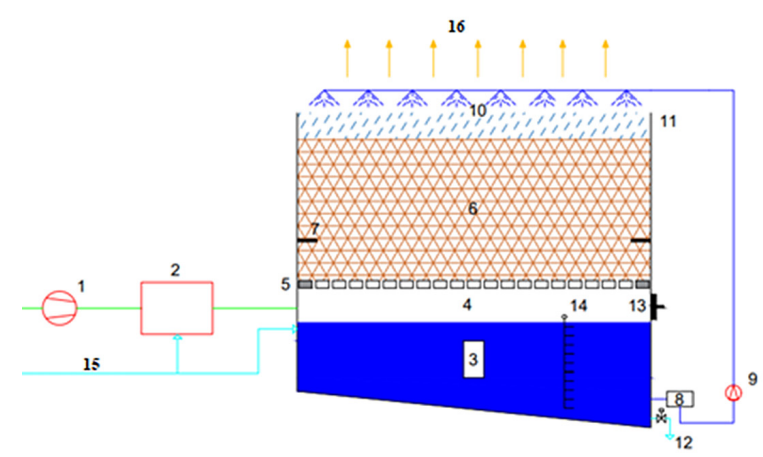

Fig. 2. Diagram of a one-stage biofilter

1. Fan

2. Humidifier

3. Tank for seep water

4. Pressure chambers

5. Slatted floor

6. Filling the biofilter

7. Rubber resistors

8. Water filter

9. Pump

10. Sprinkler system

11. Freeboard

12. Drain valve

13. Inspection opening

14. Measure the water level

15. Water supply

16. Discharge of purified gas

ensure high surface activity at low gas pressure. The large specific surface area, loose structure, and low gas flow resistance allow the process to be carried out. The filter material should have a $\mathrm{pH}$ of $7-8$, a pore volume was greater than $90 \%$, and a grain diameter greater than $4 \mathrm{~mm}$. The organic material content must not be less than 55\% [Amoore and Hautala 1983]. According to the literature, organic materials such as fertile soil with a loosened structure, peat and peat waste, compost, and wood waste are a good filling of biological filters [Chrostowski and Foster 2003].

Microorganisms easily adapt to the decomposition of impurities containing alcohols, ketones, and esters. Usually, compost naturally contains a sufficient amount and variety of microorganisms capable of biochemically breaking down complex pollutants. At the same time, microorganisms show a great ability to adapt to specific pollutants contained in the exhaust gases. For technological reasons, for the proper operation of the biofilter, such parameters as gas contact time with the bed, bed load, porosity, and specific surface area, as well as flow resistance, are important. The residence time of the gas in the biofilter depends on the type of pollutants and their solubility in water. It should be long enough for the pollutants to be absorbed in the water layer of the biofilter, and thus become available to the microorganisms responsible for biodegradation [Sówka 2008].

The filter material must create favorable conditions for the development of microorganisms in order to achieve the fastest possible biodegradation of pollutants. The physical and chemical conditions in the bed also affect the efficiency of the biofiltration process. They affect the condition and number of microorganisms responsible for the gas cleaning process. It is therefore important to ensure an optimal environment for their development. The effects of a given factor may vary depending on its type and intensity, as well as on the specific characteristics of the organism.

The factors influencing the growth, reproduction, survival, and metabolic activity of microorganisms are temperature, $\mathrm{pH}$, water content, food availability, and the level of harmful chemicals.

The temperature has the greatest and direct influence on the life processes of microorganisms. It is a factor that determines the growth rate, enzyme activity, chemical composition of cells, and nutritional requirements. It also affects the solubility of molecules of intracellular compounds, the transport of ions and diffusion of chemical substances, and the osmotic properties of cell membranes. The optimal temperature is $25-40^{\circ} \mathrm{C}$ [Kwarciak-Kozłowska and Bańska 2014].

Different microorganisms are active in various temperature ranges and should therefore be taken into account when determining the quality of the gas to be cleaned and the type of compounds removed. The bed temperature should be selected so that in a given case, the microorganisms show the greatest ss. As a result of microbiological activity, large amounts of heat can be released, causing an increase in temperature in the filter bed, this should be taken into account when designing the process. In winter, the temperature inside the biofilters may be higher than the ambient temperature by up to $10-20^{\circ} \mathrm{C}$ [Heindl 2014, Kapusta 2007, Szklarczyk et al. 2010].

An equally important factor influencing not only the viability of organisms but also the absorption of pollutants from the gas phase is humidity. As a rule, bacteria are extremely resistant to overdrying, but it may worsen the effects of biofiltration by gradually slowing down or even stopping the metabolic processes. In a dry bed, the direct contact area decreases, which in turn 
reduces the efficiency of the biofilter. For this reason, the gases may be pre-wetted before being fed to the filter bed. Not every process requires such an operation, but it is good to prepare the system in such a way that this option can be used. Excess water is also a mistake. The microorganisms inhabiting the bed are heterotrophic aerobes; thus, excess moisture can lead to the formation of anaerobic zones, causing putrefactive processes. In the event of such zones, the bed should be cleaned. The decay processes worsen the effects of deodorization and, as a result, lead to the death of mineralizing microorganisms and the suspension of the process [Szklarczyk et al., 2010, Szklarczyk, 1997].

The activity of microorganisms depends on the concentration of hydrogen ions $(\mathrm{pH})$. A neutral reaction is optimal; however, during the biofiltration of gases containing, for example, hydrogen sulfide, the substrate acidifies. The $\mathrm{pH}$ of the bed should be regulated, for example, with calcium carbonate neutralizing acids [Szynkowska and Zwoździak 2010, Kapusta 2007]. For most bacteria, the optimal $\mathrm{pH}$ value is 7.0-7.5. A drop in $\mathrm{pH}$ below 4 and an increase above 11 cause a significant reduction in bacterial activity, as well as frequent and rapid changes in the $\mathrm{pH}$ of the environment.

Various types of poisons are also a factor influencing the inhibition of the vital activity of microorganisms. Their harmfulness to the body depends on the type of toxins, as well as their dose. The substances harmful to microorganisms are heavy metals, detergents, cyanides, pesticides, and strong oxidants. They damage the cell membranes of bacteria, denature proteins or inhibit enzymes. However, out of all living organisms, bacteria are among the most resistant to environmental factors, and through adaptive processes, they can increase their resistance [Sówka et al. 2014].

By introducing a seed from a mixture of microorganisms and a nutrient solution to accelerate biofilm formation and increase the number of microorganisms, a biofilter can be prepared to break down the substances that are difficult to biodegrade, such as chlorinated hydrocarbons and most aromatic hydrocarbons (e.g. dichloromethane, benzene, toluene, xylene). Owing to such measures, very good effects of removing most of the hydrocarbons from industrial gases are obtained [Bouchy, et al. 2009), Lecińska K., 2005].
The use of biofilters in municipal waste composting plants allows for the removal of almost all of the characteristic odor-nuisance pollutants.

\section{EXPERIMENTAL PART}

\section{Materials}

The research was carried out in a composting plant. The main focus was on the elimination of inorganic odors, i.e. hydrogen sulfide and ammonia. The scope of the research included the analysis of biogas discharged from the reactor in which the composting process was carried out. The scale of the research was defined as semi-technical.

The tests were carried out on two types of biofilter filling. Each filling was analyzed every six months. The results from 2 months from startup were not included in the analysis of the results. This period was necessary for the proper development of microorganisms.

Peat (experiment I) and sawdust (experiment II) were used as a filling. Wood chips were added to increase the free space. As both peat and sawdust are acidic, the content of both biofilters was initially alkaline. For this purpose, limestone aggregate was used.

The compost mixture was bio-waste and the organic fraction of municipal waste. The filter bed was colonized by the microorganisms adapted to the decomposition of pollutants. For this purpose, active sludge was used, taken from the aeration chamber of the municipal wastewater treatment plant.

\section{Apparatus}

The composting process was carried out in a commercial composting plant, consisting of a system of 8 reaction containers with one control unit. Each container was $75 \%$ full. The capacity of a single unit was $25 \mathrm{~m}^{3}$. The external dimensions of a single container are $6.5 \times 2.4 \times 2.75 \mathrm{~m}$. The system was equipped with a temperature, humidity, and $\mathrm{pH}$ monitoring system, a leachate drainage system, and forced aeration. The containers were placed on concrete, impermeable surface.

Biofilters were installed in the biogas discharge. In order to exclude the errors caused by various weather conditions (air humidity, temperature changes), 4 containers were connected to one biofilter (experiment I) and 4 to the other 
(experiment II). The biofilters consisted of a housing (container) and a filter material filling it, inhabited by microorganisms. The volume of each biofilter was $25 \mathrm{~m}^{3}$. The contaminated gases were fed laterally according to the diagram in Figure 1.

Before the introduction of the gases into the biofilter, a steam humidifier was installed to regulate the humidity if necessary (relative humidity meter set to a minimum value of $80 \%$ ).

A system with humidification was used. The wetting process was carried out by returning the condensate and introducing it in the form of an aerosol.In order to equalize the reaction, a method of regulating the airflow was used, which involved throttles to reduce it and an additional air pump to increase it. The process was carried out for 21 days - in accordance with the technology used so far in the plant. This is sufficient time to obtain a stable material. After the process is completed, the compost matures for 6 weeks in a prism system (non-encapsulated process).

\section{Research methodology}

The parameters of the composting process with the simultaneous use of biofiltration on solid beds of odorants were determined for both the compost mixture and the filter deposit (Table 1).

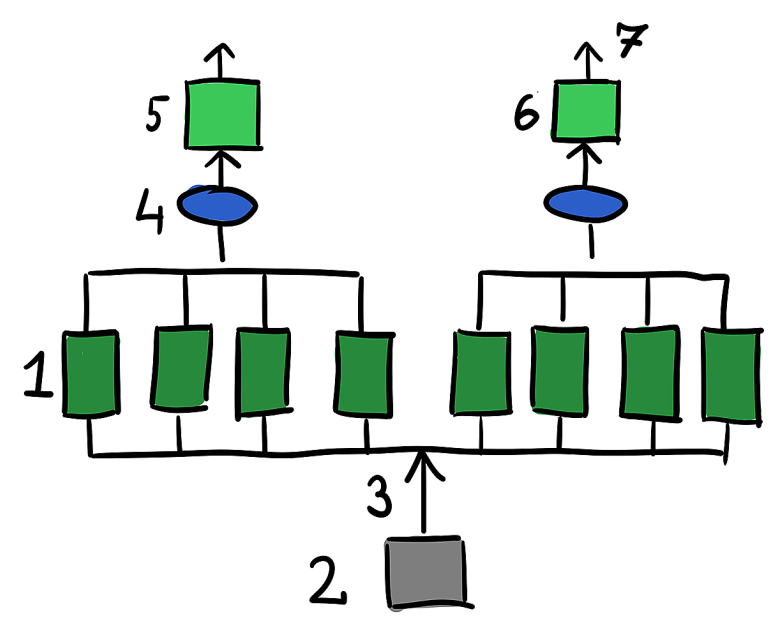

Fig. 3. Diagram of connection of biofilters

1. Compost reactors

2. Control unit

3. Airflow direction

4. Sprinklers

5. Biofilter with peat filling

6. Biofilter with sawdust filling

7. Discharge of purified gas
Composting was carried out at the mixture humidity of $50-60 \%, \mathrm{pH} 6-7$, and the aeration level of $5 \mathrm{dm}^{3} / \mathrm{min}$. All composting parameters were maintained in accordance with the guidelines.

A seed consisting of a mixture of microorganisms and a nutrient medium was introduced to accelerate the formation of biofilm and increase the number of microorganisms, which prepared the biofilter for the decomposition of the substances that are difficult to decompose biochemically (chlorinated hydrocarbons, most aromatic hydrocarbons). The optimal temperature range in the biofilter was $25-30^{\circ} \mathrm{C}$.

The biogas was taken directly after the reactor and after biofiltration. A portable biogas analyzer of the GA 5000 series, certified ATEX II $2 \mathrm{G}$ Ex ib IIA $\mathrm{T} 1 \mathrm{~Gb}\left(\mathrm{Ta}-10^{\circ} \mathrm{C}\right.$ to $\left.+50^{\circ} \mathrm{C}\right)$, IECEx, CSA was used for the analysis.

The microbiological characteristics of the filling used were carried out in order to determine the microbiological state of the filling used. The material samples were taken from the surface of the biofilter as well as from a depth of about $30-40 \mathrm{~cm}$. The samples were stored in clean, sealed containers immediately after collection. Larger fragments were ground up.

The tested samples specified:

- total number of heterotrophic bacteria

- total number of mold fungi,

- the total number of actinomycetes

- NLP of phase I and II nitrifying bacteria.

The ammonia-based nitrifying bacteria were grown on special liquid - mineral media. The cultivation was carried out at the temperature of $28^{\circ} \mathrm{C}$.

Table 1. Parameters of the compost batch and filling of bifilters

\begin{tabular}{|l|c|}
\hline \multicolumn{1}{|c|}{ Parameter } & Value \\
\hline $\mathrm{pH}$ compost mixture & $5,8-7,5$ \\
\hline $\mathrm{pH}$ filter bed & $6-7$ \\
\hline $\begin{array}{l}\text { Relative humidity of the } \\
\text { compost mixture }\end{array}$ & $45-60 \%$ \\
\hline $\begin{array}{l}\text { Relative humidity of the peat } \\
\text { filter bed }\end{array}$ & $50-60 \%$ \\
\hline $\begin{array}{l}\text { Relative humidity of the } \\
\text { sawdust filter bed }\end{array}$ & $60-70 \%$ \\
\hline $\mathrm{C} / \mathrm{N}$ (compost mixture) & $2-30: 1$ \\
\hline $\begin{array}{l}\text { Total volume of the compost } \\
\text { mixture per 1 biofilter }\end{array}$ & $75 \mathrm{~m}^{3}$ \\
\hline $\begin{array}{l}\text { Filling volume of a single } \\
\text { biofilter }\end{array}$ & $5 \mathrm{dm}^{3} / \mathrm{min}^{3}$ \\
\hline Areation & \\
\hline
\end{tabular}


The number of bacteria, actinomycetes, and fungi was determined with the Koch plate method, while the number of nitrifying bacteria by using the MPN method (the most probable number) using an appropriate inoculation system. Three series of tests were performed from each batch of material.

In addition, scrubber water from the intake air humidifier was randomly analyzed. The study aimed to determine the level of dissolved ammonia before feeding into the biofilter. The determinations were made: ammonium nitrogen according to PN-73/C-04576/02, total nitrogen, and total organic carbon using the Kiper TOC 10C Analyzer PX-120 Analyzer with the 127 AS40Dione autosamplers.

\section{Discussion of research results}

The research has shown that peat exhibits better biofiltration properties. In the case of sawdust, there were episodes of a sudden drop in $\mathrm{pH}$ in the biofilter. It was necessary to alkalize (additional liming of the deposit). This phenomenon appeared in the high-temperature phase. It should be noted that this is the phase of a rapid process, so the demand for composting microorganisms (aerobic bacteria) for oxygen, nitrogen, and carbon increases. The products of changes include, inter alia, methane, and carbon dioxide. Thus, the biofilter receives less nitrogen, including ammonium nitrogen, and more carbon dioxide. At that time, a significant decrease in efficiency of up to $80 \%$ was observed. In order to enrich and properly nourish the microorganisms, nitrogen fertilizer was used, introduced into the drainage tank.

Peat, due to the greater amount of microelements, provides better conditions for the development of microorganisms and does not require excessive feeding of nutrients. Sawdust must "work out" the conditions for the development of microorganisms. It was also noticed that the improvement of the biofilter efficiency appeared 3 days earlier than in the case of sawdust (after the process was started). In both cases, a significant decrease in the content of gaseous pollutants generated during the composting process was found. The concentrations of hydrogen sulfide and ammonia in the raw gas and after the use of a biofilter with a peat bed and a sawdust bed are summarized in Table 2. Better results were obtained with the use of a peat bed.

The lower layer of the biofilter was filled with a thicker filter material in the form of wood chips. It was the first stage of adaptation of treated biogas. The post-screening analyses showed that the development of biofilm was faster on the peat surface than on sawdust. It was also influenced by the biodiversity of nutrients contained in the peat. In the case of peat, the plate was colonized by microorganisms in greater numbers (almost twice). As it results from the conducted analyses, the $\mathrm{pH}$ in the peat deposit was kept at a neutral level.

Peat had better parameters, kept the moisture level better, and did not "settle" during the process as much as sawdust. Peat also showed a lesser tendency to decrease the humidity, while the sawdust bed reacted quite intensively with dehydration along with the temperature of the supplied air. With the loss of humidity, the share of fungi in the bed increased.

During the treatment, biological oxidation of $\mathrm{H}_{2} \mathrm{~S}$ to elemental sulfur took place by a specialized group of microorganisms from the Thiobacillus family, according to the reaction:

$$
2 \mathrm{H}_{2} \mathrm{~S}+\mathrm{O}_{2}=2 \mathrm{~S}+2 \mathrm{H}_{2} \mathrm{O}
$$

These microorganisms used carbon dioxide from the biogas as a carbon source. Elemental sulfur and sulfates were the products of the changes. Ammonia, which in principle inhibits the growth of microorganisms, was converted by nitrifying

Table 2. Average values of the removed gaseous pollutants

\begin{tabular}{|c|c|c|c|}
\hline Pollution & $\begin{array}{c}\text { Concentration } \\
\text { in front of the biofilter, } \\
\mathrm{mg} / \mathrm{m}^{3}\end{array}$ & $\begin{array}{c}\text { Concentration } \\
\text { after passing } \\
\text { through the biofilter, } \\
\mathrm{mg} / \mathrm{m}^{3}\end{array}$ & $\begin{array}{c}\text { Effectiveness } \\
\text { removal, } \\
\%\end{array}$ \\
\hline \multicolumn{4}{|l|}{ Peat bed } \\
\hline Hydrogen sulfide & 3670 & 37 & 99 \\
\hline Ammonia & 560 & 79 & 86 \\
\hline \multicolumn{4}{|l|}{ Sawdust bed } \\
\hline Hydrogen sulfide & 3588 & 574 & 84 \\
\hline Ammonia & 570 & 137 & 76 \\
\hline
\end{tabular}




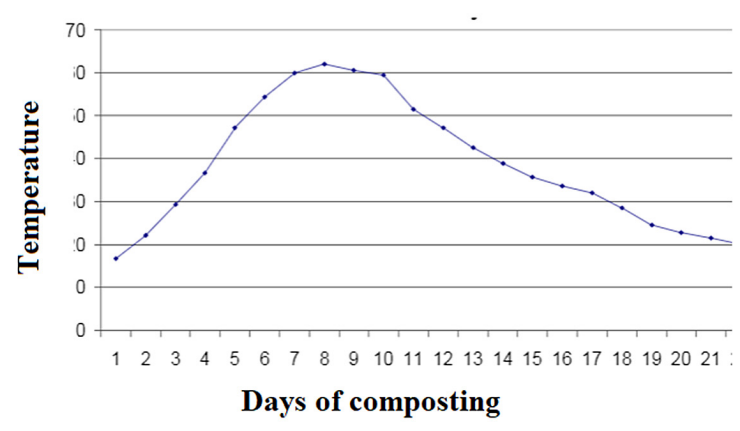

Fig. 4. Graph of temperature changes (average).

bacteria into ammonium nitrogen, which in turn was a source of nitrogen for microorganisms.

Due to the release of large amounts of heat in the microbiological processes and the composting process (especially during the first 10 days), the air discharged from the reactor was sent to the biofilter already heated. A significant increase in temperature in the dynamic phase of the composting process began as early as the third day of the process.

The obtained results indicate that the use of peat as a biofilter filling is more advantageous than sawdust filling. Peat filling shows better effects of gas cleaning; moreover, it is less cumbersome to handle, which also reduces operating costs (no need for additional liming, lower doses of nitrogen fertilizer).

The biological methods are commonly used in odorant gas purification processes, especially in the facilities with increased nuisance (wastewater treatment plants, composting plants). It allows adjusting the appropriate filtration for individual objects within one plant. The efficiency of gas cleaning, depending on the substances it contains, is in the range of $40-100 \%$. The key issue related to the proper functioning of biofilters, in addition to the use of appropriate design solutions, gas pre-treatment, and conditioning, is to ensure the optimal conditions for the development and degradation activity of microorganisms.

\section{CONCLUSIONS}

Composting facilities are potential sources of odors; however, their nuisance can be effectively reduced by air-tight sealing of devices and the use of deodorization methods. The biological methods, in particular biofiltration, are becoming more and more popular due to their simplicity and the possibility of obtaining high treatment efficiency.
The filling of the biofilter is also important. The conducted process also depends on the appropriate selection of equipment parameters (dimensions, bed layer height, and appropriate distribution of the treated gases) and proper operation ensuring their efficient operation.

Experience has shown that the type of filling has a direct impact on the ability to maintain uniform process parameters.

\section{REFERENCES}

1. Koć J. 2010. Komunalne osady ściekowe w Polsce po 1 stycznia 2013 roku. Forum Eksploatatora, 3(48).

2. Sadecka Z. 2012. Suszenie osadów - hybrydowe?, Materiały konferencyjne III Ogólnopolskiej Konferencji Szkoleniowej. Metody zagospodarowania osadów ściekowych, Chorzów, 13-14 lutego 2012, Abrys.

3. Ilski K. 2008. Semiotyka zapachów w starożytności. Symbolae Philologorum Posnaniensium Graecae et Latinae, 18, 473-489

4. Schiffman S.S., Williams C.M. 2005. Science of odor as a potential health issue. J Environ Qual, 34(1), 129-38.

5. Cain W.S. 1978. History of research on smell. In: Carterette E.C. (Ed.) Handbook of Perception. Tasting and Smelling. Academic Press, Inc., New York, 197-225.

6. Philpott C.M., Bennett A., Murty G.E. 2008. A brief history of olfaction and olfactometry. J Laryngol Otol, 122(7), 657-62.

7. Ozonek J., Korniluk M., Piotrowicz A. 2009. Uciążliwość zapachowa zakładów utylizacji odpadów zwierzęcych. Rocznik Ochrona Środowiska, 11, 1191-1199.

8. Amoore J.H., Hautala E. 1983. Odor as an Aid to Chemical Safety. J. of App. Toxicol, 3, 272-290.

9. Chrostowski P.C., Foster S.A. 2003. Odor perception and health effects. MS CPF Associates, Inc. Takoma Park, MD 20912, 1-13.

10. Sówka I., Zwoździak P., Zwoździak A., Zwoździak J. 2008. Problemy uciążliwości zapachowej wybranych obiektów gospodarki komunalnej, http:// www.pzits.not.pl/docs/ksiazki/Ekotoks_2008/ Sowka\%20409-414.pdf

11. Bouchy L. et al. 2009. Odour Creation Potential of Sludge During Composting and Drying.Water Practice \& Technology, 4(3), 1-9

12. Heindl A. 2014. Odour generation and dust in belt drying of sewage sludge, 19th European Biosolids \& Organic Resources Conference \& Exhibition. 
13. Kapusta K. 2007. Ochrona zapachowej jakości powietrza. Doświadczenia światowe w świetle potrzeby unormowań prawnych w Polsce. Prace naukowe GIG Górnictwo i Środowisko, 4, 31-50.

14. Szklarczyk M. et al. 2010. Wpływ efektów cieplnych biodegradacji zanieczyszczeń organicznych na proces biofiltracji. In: A. Musialik-Piotrowska, J.D. Rutkowski (Eds) Współczesne osiągnięcia w ochronie powietrza atmosferycznego. Materiały z X konferencji „POL-EMIS 2010”, Polanica-Zdrój 16-19 czerwca 2010 r.. PZITS, 365-368.

15. Szklarczyk M., Czemarmazowicz M. 1997. Biologiczne oczyszczanie gazów - stan obecny i perspektywy rozwoju. Biotechnologia, 108-116.

16. Szynkowska M., Zwoździak J. 2010. Współczesna problematyka odorów. Wydawnictwo NaukowoTechniczne, Warszawa 2010.

17. Lecińska K. 2005. Ograniczanie uciążliwości zapachowej w kompostowaniu odpadów, Przegląd
Komunalny, 11, 170.

18. PN-Z-15011-3: 2001

19. PN-EN 13183-1: 2004.

20. PN-EN 15936: 2013-02.

21. PN-EN 15407: 2011.

22. PN-ISO 7150-1.

23. PN-73/C-04576/02.

24. PN-EN 13725:2007.

25. Kwarciak-Kozłowska A., Bańska B. 2014. Biofiltracja jako metoda unieszkodliwiania odorów powstających podczas kompostowania frakcji biodegradowalnej odpadów komunalnych i przemysłowych. Inżynieria i Ochrona Środowiska. 17, 4, 631-645.

26. Sówka I., Miller U., Sobczyński P. 2014. Emisja odorów z procesów kompostowania odpadów komunalnych. Przemysł Chemiczny, 1, 93(15), 1000-1003. 